\title{
The mediating effect of business ethics in the relationship between total quality management and sustainable performance: perspective from 4- and 5-stars hotels
}

\section{Kit-Yeng Sin*}

Faculty of Economics and Business,

Universiti Malaysia Sarawak,

94300 Sarawak, Malaysia

Email: kysin@unimas.my

*Corresponding author

\section{Choon Ling Sim}

School of Business Innovation and Technopreneurship,

Univesiti Malaysia Perlis,

01000 Kangar, Perlis, Malaysia

Email: clsim89r@gmail.com

\section{Yi Jin Lim}

HK Gaosheng Education Consultants Sdn Bhd, Malaysia

Email: asdeyu@gmail.com

\section{Damien Lee and Joanne Shaza Janang}

Faculty of Economics and Business,

Universiti Malaysia Sarawak,

94300 Sarawak, Malaysia

Email: liydamien@unimas.my

Email: sjjoanne@unimas.my

\begin{abstract}
Sustainability and ethical issues in hotel industries have received great attention in recent years. This report is the outcome of a field research, which aimed to determine the relationship between TQM, business ethics and sustainable performance. The focus of this research is 4- and 5-stars hotels in Malaysia, in which 162 4- and 5-stars hotels are sampled. Quantitative approach is adopted in which structural equation modelling is employed to assess the relationship between TQM practices, business ethics and sustainable performance. The findings of this study indicate that TQM has positive impact on sustainable performance. Hence, it is concluded that the hoteliers in Malaysia are vigorously focusing on implementation of TQM practices in order to achieve sustainability. Besides, these research findings show that business ethics play as the role of mediator in the relationship of TQM and sustainable performance. The proposed framework serves as a guideline to verify the significance of TQM practices as well as business ethics in order to leverage the hotels' sustainable performance.
\end{abstract}


Keywords: total quality management; TQM; sustainable performance; business ethics; structural equation modelling; SEM.

Reference to this paper should be made as follows: Sin, K-Y., Sim, C.L., Lim, Y.J., Lee, D. and Janang, J.S. (2021) 'The mediating effect of business ethics in the relationship between total quality management and sustainable performance: perspective from 4- and 5-stars hotels', Int. J. Productivity and Quality Management, Vol. 34, No. 2, pp.176-204.

Biographical notes: Kit-Yeng $\operatorname{Sin}$ is a Lecturer in Universiti Malaysia Sarawak. She has successfully completed her Doctoral in Management, Master's in Engineering Management as well as Bachelor's of Engineering (honours) in Biomedical Electronics Engineering at the Universiti Malaysia Perlis (UniMAP). She is currently involved with various tourism research projects. Her areas of expertise include operational management, quality management, sustainability, multi-criteria decision making, tourism management and organisational behaviour.

Choon Ling Sim holds a Bachelor's in Biomedical Electronic Engineering (first class hons.), Master's of Business Administration (MBA) major in Engineering Management and has successfully completed her Doctoral in Management at the University Malaysia Perlis. Her areas of research interest are in quality management, lean, Six Sigma and Lean Six Sigma practices.

Yi Jin Lim obtained her Diploma in Retailing from the Polytechnic Ungku Omar (PUO), Perak, Malaysia in 2010 and Bachelor's in International Business from the Universiti Malaysia Perlis (UniMAP), Perlis, Malaysia in 2013. In the same year, she continued her study in Master's of Science, major in marketing at the same university and had graduated in 2015 . She has recently completed her doctoral, major in marketing at the Universiti Utara Malaysia (UUM) in Sintok, Kedah Malaysia. She has published 15 articles including five co-authorship articles so far. Her research interests are marketing, green marketing as well as in management.

Damien Lee is a Lecturer at the Universiti Malaysia Sarawak. He has completed his Doctoral in Auditing at the Universiti Sains Malaysia, Master's in Finance at the University Technology, Sydney, and successfully writes his professional Chartered Certified Accountant qualification with The Association of Chartered Certified Accountants (ACCA), UK. He is currently involved with various research projects and delivered diverse educational courses at tertiary levels. He is also a member of few accounting professional bodies, Malaysian Institute of Accountants (MIA), ASEAN Chartered Professional Accountant (ACPA) and ACCA.

Joanne Shaza Janang is currently an Accounting and Finance Lecturer at the Faculty of Economics and Business, Universiti Malaysia Sarawak. She has completed her Diploma in Accountancy and Bachelor's of Accountancy (honours) at the Faculty of Accountancy, Universiti Teknologi MARA, Sarawak. She received and was awarded Master's of Science in Accountancy (Research) at the Faculty of Accountancy, Universiti Teknologi MARA, Shah Alam in 2018. She completed her Master's in less than two years and hence was awarded the Graduate on Time-GOT award by Universiti Teknologi MARA. The award was granted during the Innovation and Research Appreciation Award Ceremony organised by Universiti teknologi MARA, Selangor. She has also presented in several colloquiums and conferences such as the International Conference on Accounting and Muamalat. She is also active in assisting the faculty in many areas such as a member of the UPIK team and the coordinator of industry and community engagement. 